\title{
Classification of Serwan river Levee's Soils in Kurdistan Region- Iraq
}

\author{
Salim Neimat Azeez
}

Darbandikhan Technical Institute, Sulaimani Polytechnic University, Darbandikhan, Al Sulaymaniah, Kurdistan Region, Iraq

Email:Dr.salimn@gmail.com

\section{Abstract}

The study was conducted in order to classify Levee's Soil of Serwan river and to know the dominant soil units in the study area, as well as to determine the dominant pedogenic processes in the study area. Four pedons were selected along Sirwan River and described morphologically. Soil samples were taken from each soil horizon to determine some physical and chemical properties. The results showed that all pedons are developed with A-B-C horizon sequences. All pedons have a Mollic epipedons with Agrillic and Calcic endopedons. The The increase of fine and total clay are due to the activity of Eluviation and illuviation pedogenic processes and to some extent to the new formation of clay minerals. According to the morphological, physical and chemical properties of the studied pedons, soils were classified as Typic Argixerolls as they have Mollic surface horizons with more than $50 \%$ base saturation for more than $175 \mathrm{~cm}$ depth. They have Argillic and Calcic subsurface horizons. The results indicated that the dominant pedogenic processes affecting soil development are eluviation, illuviation, decalcification and calcification.

Keywords: Soil , Soil Genesis, Soil Classification

\section{Introduction}

Soil is one of the main resources for most terrestrial life. Soil Sciences study soils from many different perspectives for agriculture, construction and mining. Agriculturally, Soil Science has two main branches, Edaphology and Pedology. Edaphology was defined by Porta et al., (1994) as "the study of the community of microflora and microfauna in the soil (edaphon) and the processes that govern their existence and development (edaphogenesis)". Pedology was defined by Gregorich et al., (2001) as" the study of soils that integrates their distribution, formation, morphology and classification as natural landscape bodies".

Iraqi soils show different degrees of development according to the effects of local conditions: calcareous parent materials, geomorphology, semi-dry climatic , and grass. 
They are generally classified as : Aridisols, Inceptisols, Entisols , Mollisols and Vertisols (Muhaimeed and Sulaiman, 1990, Muhaimeed, 1994; Al-Agidi, 1986, Muhaimeed et al., 2000 and Muhaimeed et al., 2014 ). Inceptisols show a wide variety of soils. In some areas these soils have minimal development, whereas in other areas these soils have diagnostic horizons that merely fail the criteria of other soil orders. They have many kinds of diagnostic horizons and epipedons. The most common horizon sequence is Ochric epipedon over a Cambic horizon . Mollisols commonly are darkcolored, base-rich mineral soils of the steppes. Nearly all of these have a Mollic epipedon, and many have an Argillic, and Calcic horizon. Many of these soils developed under grass and many apparently were forested. Soils of Kalar city, located in Northern Iraqi Kurdistan region, are the main sources for food production in the region as they are highly fertile soils with high organic matter and available nutrients .They are mostly belong to Mollisols and Inceptisols formed from calcareous parent material and under grasses vegetation ( Muhaimeed et al., 2013) .

Due to the lack of the semi-detail work on the genesis and classification of soils in the study area, this study was conducted in order to :

1- Diagnosis the dominant pedogenic processes responsible for soil formation of the study area.

2- To classify soils of the study area using Soil Taxonomy.

\section{Materials and Methods}

Location of the Study Area:

The study area is located in, Iraqi Kurdistan region, Garmian, Kalar city, alongside Serwan river. Two sites were chosen, the first was in Banzamen village laying between $34^{\circ} 39^{\prime} 52.2^{\prime \prime} \mathrm{N}$ and $45^{\circ} 25^{\prime} 02.2^{\prime \prime} \mathrm{E}$ with elevation of $205.4 \mathrm{msal}$ (meter above sea level), whereas the second was in Qaracham village at $34^{\circ} 50^{\prime} 26.5^{\prime \prime} \mathrm{N}$ and $45^{\circ} 32^{\prime} 15.4^{\prime \prime}$ E with elevation 308 msal ( Figure1). 


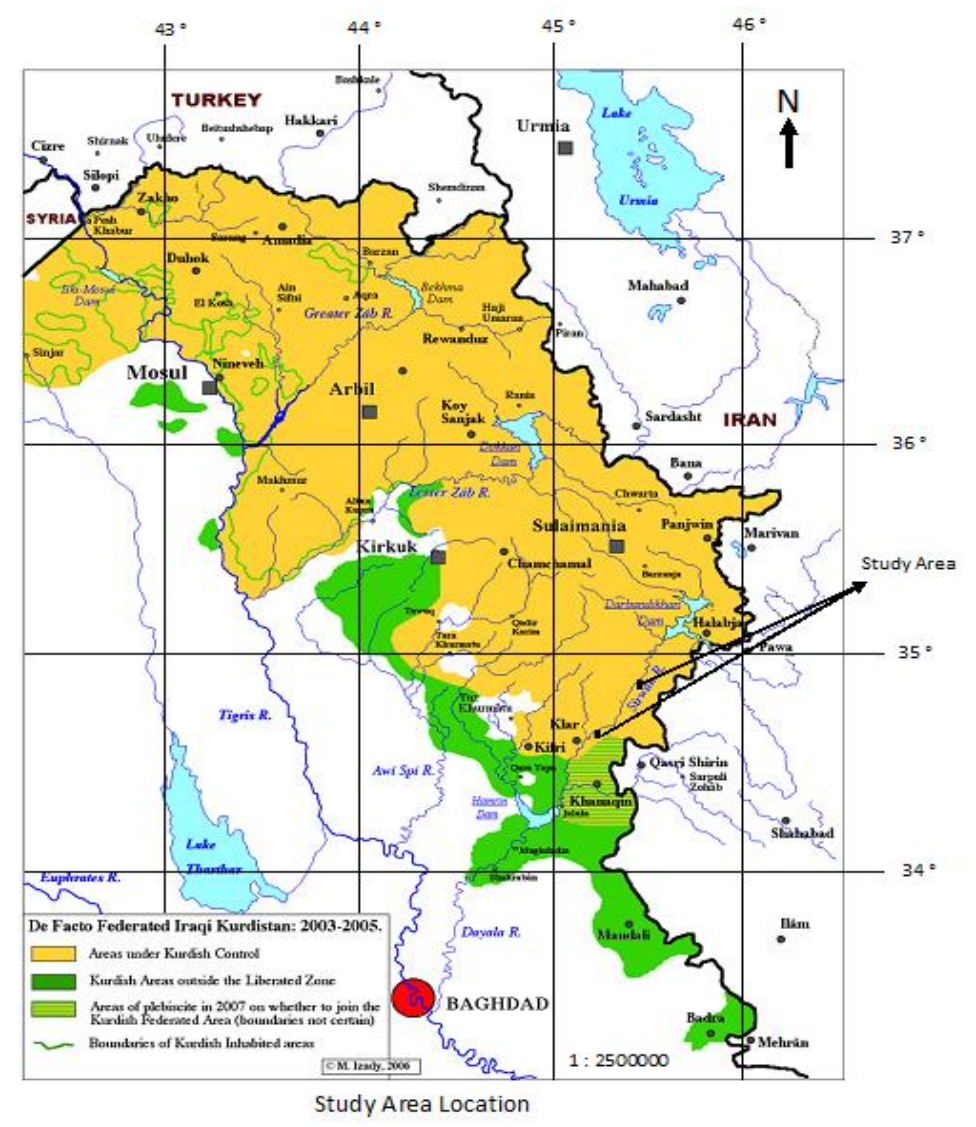

Figure 1: Location of the study area

\section{Geology of the Study Area}

The study area is located in foot hill physiographic unit (Buring, 1960), but in tectonic side the study area is lies within folds zone as pointed by (Dunnington, 1958). The region is formed through Miocene and Pliocene duration (Buring, 1960), Where Miocene duration include Lower Fars sediments which formed from gypsum rocks, limestone and maral while the Upper Fars which formed from siltstone, limestone and maral (Naqash and Hambarsom, 1985). But the Pliocene duration include Lowe Bakhtiary formation which include siltstone, sandstone, maral with gravel and Upper Bakhtiary which include thick sediments of conglomerate (Buring, 1960).

\section{Climate of the Study Area}

The climate of the study area is continental semi arid (Kharrufa, 1985), the precipitation is mostly rainfall with few snow falling especially in winter and at the first months in spring, the average of rainfall is $(330 \mathrm{~mm} /$ year) while the average of temperature is (22 $\left.\mathrm{C}^{\circ}\right)$, the high rainfall was in 2004 with $(550 \mathrm{~mm} / \mathrm{year})$ but the lowest was in 2008 which recorded (168 mm/year) from years 2001-2014 (Garmian Agriculture Office). 


\section{Land Use and Natural Vegetation}

There are several types of natural plants such as Carthamusoxyacanthus, Loliumrigidum, Cynodondactylon, Ammi majus, Phalaris minor, Trifloliumresupinatum, EuphorbiaPeplus, Lagonychiumfarctum, Hordeumglaucum, Centaureaiberica, Avenafatua, Alhagigraeccorum (FAO, 2000). The study area is used for field crops production especially Triticum spp and Hordeum spp also used for vegetation crops, under dry farming and supplemental irrigation system using water irrigation from Serwan river.

\section{Field Works}

A topographic map (Ahmad, 2005) and a reconnaissance soil survey map (Muhaimeed et al., 2014) were used as basic maps for this study. Four pedons sites were selected represent all the variations in the study area . One Pedon was drilled in each location, and described morphologically according to (Soil Survey Staff, 1993). Soil samples were taken for physical and chemical properties determinations. Soils were classified According to the Keys to Soil Taxonomy (Soil Survey Staff, 2006).

\section{Physical Properties}

Soil particle size distribution was determined by using the International Pipette Method as described in (Kilmer and Alexander, 1949). The Silt and Clay were separated from Sand by washing the dispersed samples through a $50 \mu$ sieve, as described in (Jackson, 1956). The various Clay fractions were thus obtained by pipette method as described in (Jackson, 1979). Fine clay was determined according to(Avery and Bascomb, 1982). Bulk density was measured by clod method using Paraffin Wax, as described by (Blake, $1965_{\mathrm{b}}$ ), that cited in (Black, 1965). Particle density was measured by pycnometer method, as described by (Blake, 1965a), which cited in (Black, 1965). The porosity was calculated using the equation [1] according to (Vomocil, 1965), which cited in (Black, 1965) as follows:

$\%$ Porosity $=\{1-($ bulk density $/$ particle density $)\} \times 100$

\section{Chemical Properties}

Organic carbon (OC) was determined by wet oxidation method using chromic acid according to the method of (Walkley-Black, 1934), which was described by (Hesse, 1972). The organic carbon can converted to organic matter by the equation below:

Organic matter $=$ Organic carbon $\times 1.72 \quad \ldots . . . . . . . .[2](J a c k s o n, \quad 1958$ and Nelson and Sommer, 1982).

Total carbonate was measured by equilibrium with (1N) of hydrochloric acid, depending upon (Piper, 1950), as described by (Hesse, 1972). Active carbonate was measured after 
precipitation as a calcium oxalate, by using $0.1 \mathrm{M}$ of ammonium oxalate according to (Galet, 1972). Soil reaction $(\mathrm{pH})$ was measured in a saturated soil paste extract which described by (Richards, 1954) using pH meter device, model-pH 211-Microprocessor pH meter-HANNA Com.-Italy. Electric conductivity (ECe) of extract was measured according to the $4 \mathrm{~b}$ method, as described by (Richards, 1954), using EC meterLovibond - con 200 - Germany. Cation exchangeable (CEC)capacity was measured by using calcium chloride as saturated solution $(0.5 \mathrm{M}$ at $\mathrm{pH}=7)$, followed by removing calcium chloride with sodium nitrate $(1 \mathrm{M})$ and the removed calcium measured according to (Papanicolaou, 1976).

\section{Exchangeable Cations}

Exchangeable calcium measured in soil paste extract treated with sodium acetates as described in (Chapman and Pratt, 1961), then the exchangeable calcium titrated with E.D.T.A. (Ethyl diamine tetra acetic acid) as a chelating substance, to take off calcium ions, at $\mathrm{pH}=12$ by using sodium hydroxide $(4 \mathrm{M})$ and muroxide indicator as vercenite titration method which described in (Yoseef, 1999). Exchangeable magnesium was measured in the soil paste extract which treated with sodium acetate, as mentioned in (Chapman and Pratt, 1961), whereas exchangeable calcium and magnesium were measured, then the amount of exchangeable magnesium was calculated by subtracting the amount of exchangeable calcium from the amount of exchangeable calcium plus magnesium, as described by (Yoseef, 1999).

Exchangeable sodium and potassium was measured taken five grams of soil samples were saturated by ammonium acetate (1M) as described in (Kelley, 1948), the exchangeable sodium and potassium were measured by Compact ion meter device, model-HORIBA Kyoto 60 - 8510. Japan Cod $\mathrm{K}^{+} \mathrm{C}-131, \mathrm{Na}^{+} \mathrm{C}-122$. Base saturation percentage (B.S.P.) was calculated by using the following equation:

$$
\text { B.S. } \mathrm{P}=\frac{\text { Total Exchangeable Cations }}{\text { Cation Exchangeable capacity }} \times 100 \ldots \ldots \ldots \text {..... [3] }
$$

\section{Results and Discussion}

According to the results of the morphological description of the studied pedons ( Table 1 ) all the pedons represent developed soils with A-B-C profiles .All pedons have dark color and deep surface horizons meet the criteria of Mollic epipedon ( Soil Survey Staff, 2010). The studied soil profile macromorphology show the following features: clear and abrupt transition becomes diffuse and clear or gradual among the horizons when the soil evolution increases. Granular macrostructure on the surface horizons and sub angular 
blocky on the subsurface horizons. The degree of development of these soils is reflected by the horizon number and thickness on soil profiles depth.

Table 1: Morphological characteristics of the studied pedons

\begin{tabular}{|c|c|c|c|c|c|c|c|}
\hline Site & Pedon & Horizon & Depth (cm) & Color (D) & Structure* & Consistence (D) & Boundary \\
\hline \multirow{8}{*}{ 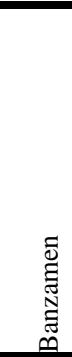 } & \multirow{4}{*}{1} & Ap & $0-25$ & $(10 Y R$ 5/3) & 1 med. gr & Soft & Clear Smooth \\
\hline & & Btk & $25-90$ & (10YR 5/4) & 3 med. bk & Hard & Clear Smooth \\
\hline & & $\mathbf{C k}_{1}$ & 90-117 & $(10 Y R$ 7/3) & 2 fine sbk & Slightly Hard & Clear Smooth \\
\hline & & $\mathbf{C k}_{2}$ & $117-150$ & (10YR 7/4) & 2 fine sbk & Soft & Clear Smooth \\
\hline & \multirow{4}{*}{2} & $\overline{A p}$ & $0-30$ & $(10 Y R$ 5/3) & 2med.sgr & Soft & Diffused Smooth \\
\hline & & Btk $_{1}$ & $30-95$ & (10YR 5/4) & 2 fine sbk & Hard & Clear Smooth \\
\hline & & Btk $_{2}$ & $95-125$ & (10YR 7/2) & 2 med.sbk & Hard & Clear Smooth \\
\hline & & Ck & \begin{tabular}{|l|}
$125-160$ \\
\end{tabular} & $(10 Y R$ 7/3) & 2 fine sbk & Soft & Clear Smooth \\
\hline \multirow{9}{*}{ 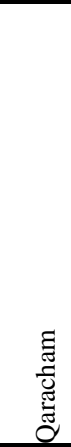 } & \multirow{5}{*}{1} & $\mathbf{A P}$ & $0-30$ & (10 YR 5/1) & 2 med.gr & Hard & Abrupt Smooth \\
\hline & & Btk $_{1}$ & $30-50$ & (10YR4/2) & 3 med.sbk & Hard & Clear Smooth \\
\hline & & Btk $_{2}$ & 50-90 & $(7.5 Y R$ 6/3) & 2 fine sbk & Slightly Hard & Diffused Smooth \\
\hline & & $\mathbf{C k}_{1}$ & 90-130 & $(10 Y R$ 6/3) & 2 med.sbk & Hard & Diffused Smooth \\
\hline & & $\mathrm{Ck}_{2}$ & 130-150+ & $(7.5 Y R 6 / 3)$ & 2 fine sbk & Slightly Hard & Clear Smooth \\
\hline & \multirow{4}{*}{2} & Ap & $0-25$ & $(10 Y R$ 5/2) & 2 med.gr & Hard & Clear Smooth \\
\hline & & Btk $_{1}$ & $25-100$ & (10YR 5/3) & 2 med.sbk & Hard & Diffused Smooth \\
\hline & & Btk $_{2}$ & $100-140$ & $(10 Y R 5 / 4)$ & 3 med.sbk & Slightly Hard & Diffused Smooth \\
\hline & & $\mathbf{C k}$ & \begin{tabular}{|l|}
$140-170$ \\
\end{tabular} & (10YR 6/4) & 2 fine sbk & Slightly Hard & Clear Smooth \\
\hline
\end{tabular}

* $1=$ weak $2=$ moderate $3=$ strong $\mathrm{gr}=$ granular $\mathrm{sbk}=$ sub angular blocky med.= medium

The color is brown to dark brown indicating good drainage, and intense surface darkening, due to high organic matter contents, which make soil more friable when moistened. The surface horizons of studied soils are deep, dark brown with chroma and value less than 5.5 for dry soil samples with more than $2.5 \%$ organic matter to more than $50 \mathrm{~cm}$ soil depth. These properties meet the criteria of Pachic condition( Soil Survey Staff , 2010). The presence of Pachic conditions are due to the interaction of environmental conditions and vegetation factors causing high activity of the melanization process represented by the accumulation organic, decomposition and mixing of organic matter with mineral soil components leading to the formation of deep dark surface horizon rich with organic matter content. According to the results of soil properties and the environmental conditions allowed to conclude that surface horizons were developed from interactions among climate and vegetation that induces the leaf fall and the their decomposition and mixing with the mineral soil components. 
The results of soil particle analysis ( Table 2 ) indicate that silt content was the dominant fraction followed by clay and sand in the studied pedons due to the effect of parent material and to some extent to the geomorphic and climatic conditions. Amount of total clay and fine clay show the same pattern of distribution with in all the studied pedons ( Figure 2 ). They increase with depth at Bt horizons and decrease in $\mathrm{C}$ horizons .This type of distribution may be due to the effect of pedogenic processes and to some extent to the in situ clay formation. The main pedogenic processes are eluviation and illuviation causing clay translocation from the surface horizons to subsurface horizons ( $\mathrm{Bt}$ ).

Movement of clay particles and colloids through the soil profile has been investigated extensively during the past decades. This movement has significant impacts environmentally and pedologically. This movement is important environmentally because heavy metals, pesticides, or fertilizers can be translocated to the ground water and contaminate it via their adsorption on mobile clay particles (Ryan et al., 1998 and Sprague et al., 2000). This movement is also important pedologically because formation of some soil diagnostic horizons, such as the Albic, Argillic and Spodic horizons, is concomitant with clay particle movement (Soil Survey Staff, 1999). McKeague and St. Arnaud (1969) and Dixit (1978) stated that clay particles can move downward from the upper horizons and deposit in the lower horizons. The process of clay particles translocation in suspension downwards is known as lessivage (Schaetzl and Anderson, 2005). Factors affecting clay movement were suggested by different researchers. Zhuang and others (2007) and Sharma and others (2008) attributed the colloidal movement in soils to the moving air-water interface. Michel and others (2010) suggested that colloid movement is affected by gravitational water drainage, water evaporation from the soil and water profile redistribution from preferential flow paths toward the soil pores. Clay translocation by lessivage, is generally described as beginning with chemical or physical dispersion of fine clays along a macro pore, followed by downward movement as suspended load in leaching pore water and ending with deposition (Eswaran and Sys, 1979; Miller, 1983 and Phillips, 2007). The depth of clay deposition in the solum is thought to be controlled by wherever pore size becomes so small as to constrict water flow, a pore is partially plugged by illuviated clays from prior episodes of translocation , or, pore water is pulled into side pores via capillarity which leaves the clays lining the original macro pore (Thorp and Smith, 1949), or, by flocculation as the clays encounter increased soil $\mathrm{pH}$ and ionic strength in the lower solum.

Distribution pattern of total and fine clay in all studied pedons indicates significant differences between the eluvial and illuvial horizons. The value of the average clay content in B horizons to the average value of clay content in A horizon is more than 1.2, 
which meets the criteria required for the formation of Argillic horizon (Soil Survey Staff, 1999). Total clay, fine clay contents and the percentage of fine clay to total clay are at their maximum in Btk horizons and decrease with depth in all pedons of the study region (Figures 2,3).
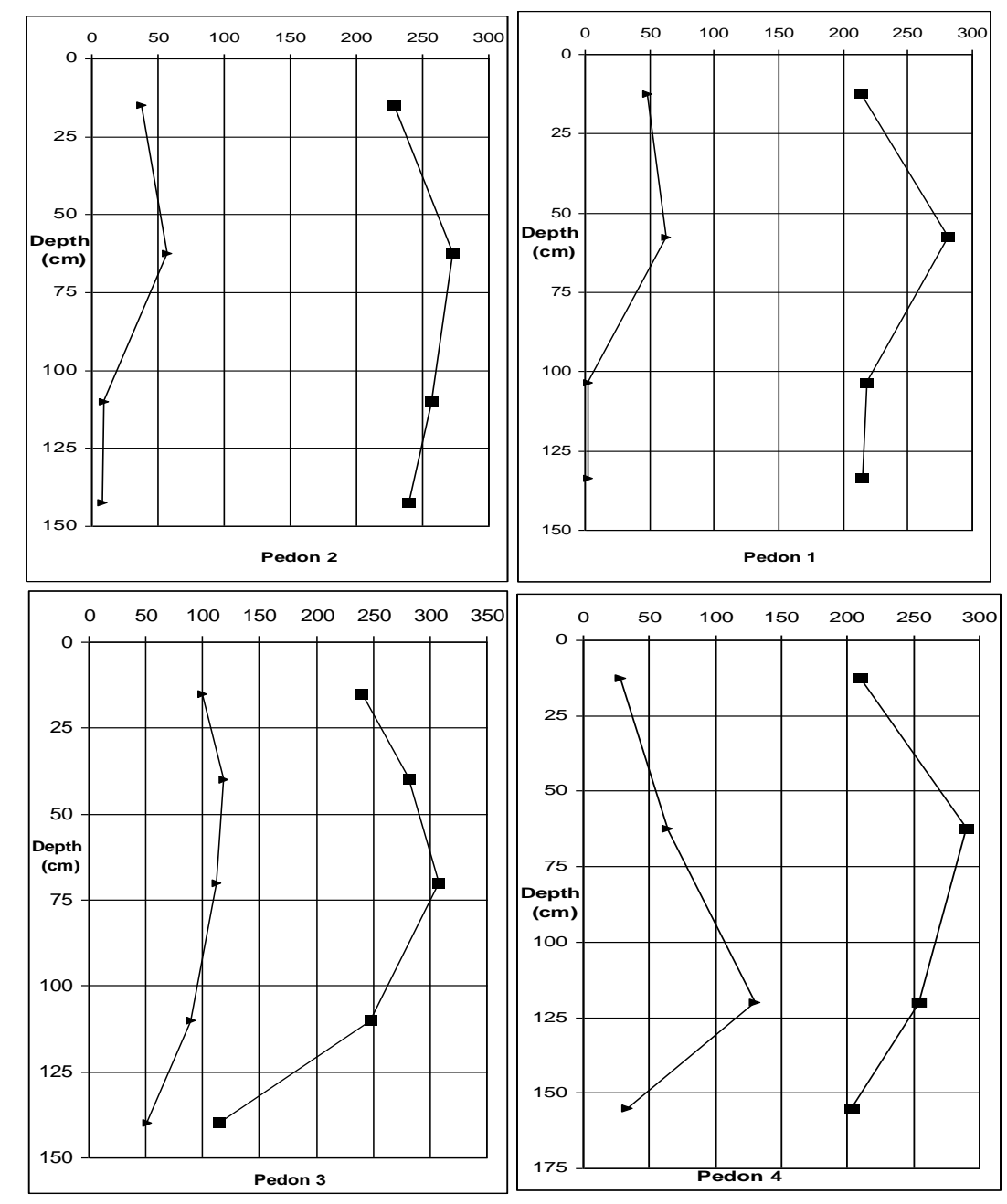

Total Clay $(g / k g)$

Fine Clay $(\mathrm{g} / \mathrm{kg})$

Figure 2: Distribution of total and fine clay in the study pedons. 

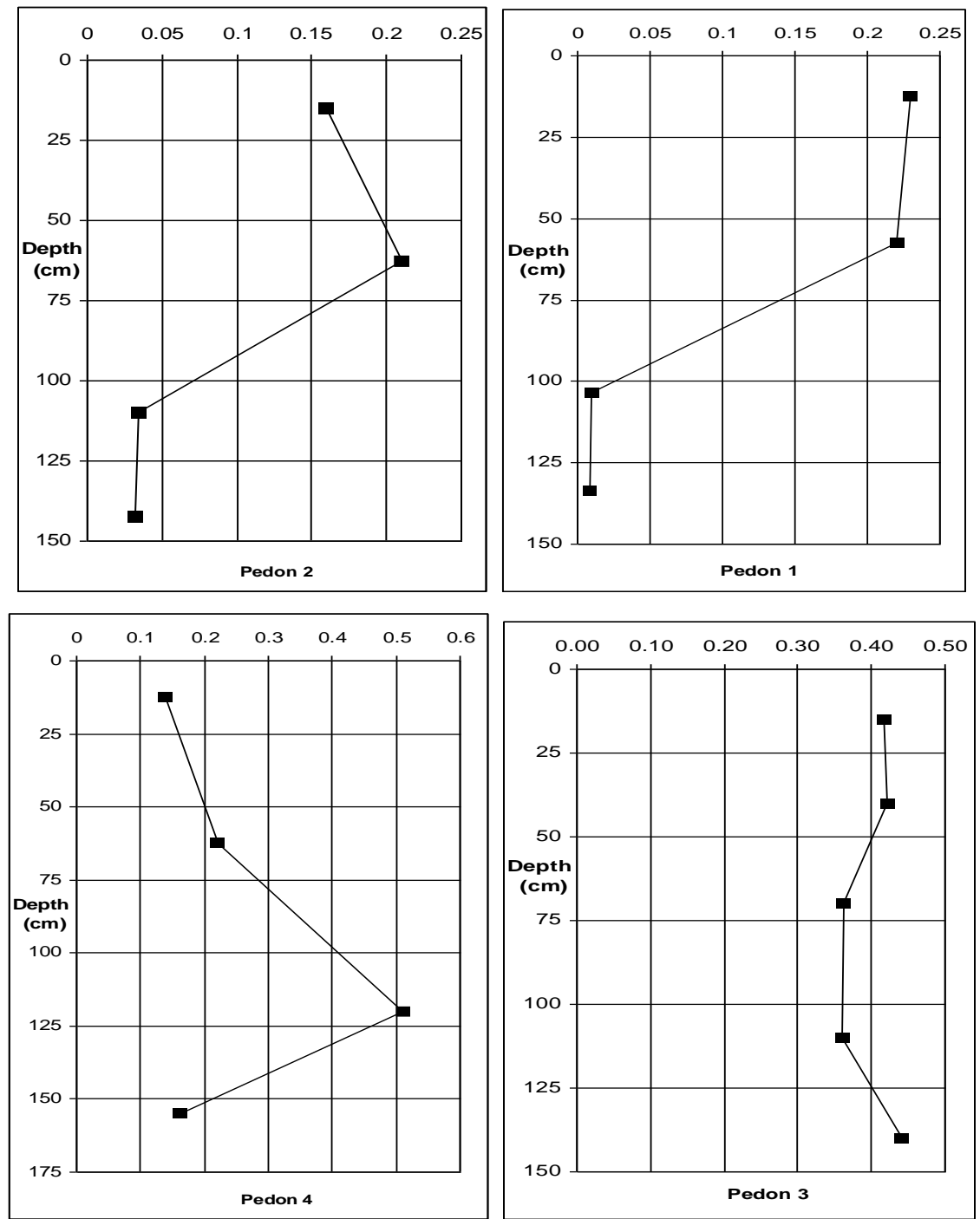

Fine Clay / Total Clay

Figure 3 : Distribution of fine / total clay in the study pedons.

The increment of clay content in illuvial horizons comparison to eluvial horizons seems to be sufficient to meet the criteria for Argillic horizon formation. However, the presence of Argillic horizons in all pedonscan not be related to semiarid climatic conditions of the study area, but may be greatly related to the effect of the paleo-climatic conditions, which were more humid than the dominant conditions of the present days. This fact reflected by the presence of Calcic horizons within the depth of Argillic horizons within these pedons which may caused by the new addition of calcareous materials to these pedons from the upland area by erosion and sedimentation processes during the dry period( Muhaimeed et al.,2013 ). 
The results of some chemical properties ( Table 3and Figure 4) show that the amount for both total and active carbonate increase with depth at $\mathrm{Bk}$ then decrease at lower horizons in all of the studied pedons. The amount of carbonate in all pedons increased in the subsurface horizons to the level required for Calcic horizon formation, for example, in the depth 20 to $65 \mathrm{~cm}\left(\mathrm{Btk}_{1}\right.$ and $\left.\mathrm{Btk}_{2}\right)$ in Pedon 4 with the identification of the presence of $>5 \%$ volume of carbonate accumulated as soft powder or small nodules of identifiable secondary carbonates in these horizons (Soil Survey Staff , 2010).

Table 3: Some chemical properties of the study pedons.

\begin{tabular}{|c|c|c|c|c|c|c|c|c|c|c|c|c|c|c|}
\hline \multirow{2}{*}{ site } & \multirow{2}{*}{ Pe.* } & \multirow{2}{*}{ Ho.* } & \multirow{2}{*}{$\begin{array}{l}\text { Depth } \\
(\mathrm{cm})\end{array}$} & O.C. & Total & Active & \multirow{2}{*}{$\begin{array}{l}\mathrm{pH} \\
\text { (ex.*) }\end{array}$} & \multirow{2}{*}{$\begin{array}{l}\mathrm{ECe} \\
(\mathrm{ds} / \mathrm{m})\end{array}$} & \multicolumn{4}{|c|}{ Exchangeable Cations $\left(\mathrm{cmol}_{\mathrm{c}} / \mathrm{kg}\right.$ soil) } & \multirow{2}{*}{$\begin{array}{l}\mathrm{CEC} \\
\left(\mathrm{cmol}_{\mathrm{c}} / \mathrm{kg}\right. \\
\text { soil })\end{array}$} & \multirow{2}{*}{ BSP } \\
\hline & & & & \multicolumn{3}{|c|}{$\mathrm{g} \mathrm{kg}^{-1}$ soil } & & & $\mathrm{Ca}^{+2}$ & $\mathrm{Mg}+{ }^{2}$ & $\mathrm{Na}^{+}$ & $\mathrm{K}^{+}$ & & \\
\hline \multirow{8}{*}{ 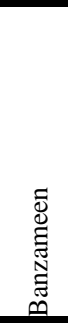 } & \multirow{4}{*}{1} & Ap & $0-25$ & 7.74 & 280 & 110 & 7.69 & 0.65 & 23.88 & 1.25 & 1.26 & 0.28 & 29.8 & 89.50 \\
\hline & & Btk & $25-90$ & 3.32 & 290 & 105 & 6.97 & 1.79 & 22.21 & 1.25 & 1.17 & 0.19 & 27.4 & 90.58 \\
\hline & & $\mathrm{Ck}_{1}$ & $90-117$ & 0.52 & 220 & 100 & 7.4 & 2.23 & 19.08 & 1.24 & 1.33 & 0.18 & 24.35 & 89.65 \\
\hline & & $\mathrm{Ck}_{2}$ & $117-150$ & 0.39 & 260 & 80 & 6.91 & 2.25 & 18.71 & 1.23 & 1.24 & 0.17 & 22.86 & 93.39 \\
\hline & \multirow{4}{*}{2} & Ap & $0-30$ & 7.67 & 305 & 100 & 7.74 & 0.57 & 20.81 & 1.1 & 1.2 & 0.23 & 25.9 & 90.12 \\
\hline & & $\mathrm{Btk}_{1}$ & $30-95$ & 3.26 & 325 & 105 & 7 & 1.65 & 20.02 & 1.08 & 1.09 & 0.11 & 25.41 & 87.76 \\
\hline & & $\mathrm{Btk}_{2}$ & $95-125$ & 0.41 & 260 & 85 & 7.32 & 2.36 & 17.34 & 1.06 & 1.22 & 0.07 & 23.55 & 83.61 \\
\hline & & $\mathrm{Ck}$ & $125-160$ & 0.29 & 280 & 75 & 7.1 & 2.28 & 18.71 & 1.01 & 1.2 & 0.06 & 24.71 & 84.90 \\
\hline \multirow{9}{*}{ 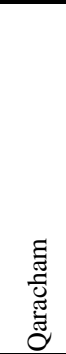 } & \multirow{5}{*}{3} & Ap & $0-30$ & 9.31 & 165 & 100 & 7.33 & 0.85 & 24.41 & 0.49 & 1.87 & 0.67 & 29.62 & 92.64 \\
\hline & & $\mathrm{Btk}_{1}$ & $30-50$ & 5.72 & 175 & 100 & 7.32 & 0.55 & 23.14 & 0.39 & 1.85 & 0.54 & 28.57 & 90.72 \\
\hline & & $\mathrm{Btk}_{2}$ & $50-90$ & 3.51 & 295 & 110 & 7.21 & 0.51 & 24.35 & 0.28 & 1.63 & 0.41 & 29.7 & 89.80 \\
\hline & & $\mathrm{Ck}_{1}$ & $90-130$ & 0.77 & 380 & 60 & 7.27 & 0.48 & 20.01 & 0.19 & 1.74 & 0.33 & 25.97 & 85.75 \\
\hline & & $\mathrm{Ck}_{2}$ & 130-150+ & 0.6 & 320 & 110 & 7.19 & 0.59 & 17.17 & 0.14 & 1.79 & 0.38 & 22.99 & 84.73 \\
\hline & \multirow{4}{*}{4} & Ap & $0-25$ & 8.02 & 240 & 75 & 7.72 & 0.65 & 20.44 & 4.96 & 1.26 & 0.1 & 30.09 & 88.93 \\
\hline & & $\mathrm{Btk}_{1}$ & $25-100$ & 5.29 & 330 & 115 & 7.15 & 0.58 & 17.1 & 3.87 & 1.05 & 0.08 & 25.99 & 85.03 \\
\hline & & $\mathrm{Btk}_{2}$ & 100-140 & 0.58 & 315 & 105 & 7.1 & 0.5 & 15.08 & 3 & 0.99 & 0.06 & 22.45 & 85.21 \\
\hline & & $\mathrm{Ck}$ & $140-170$ & 0.29 & 255 & 90 & 7.69 & 0.45 & 14.12 & 3.01 & 1.03 & 0.04 & 21.78 & 83.56 \\
\hline
\end{tabular}

$* \mathrm{Pe}=$ Pedon

$* \mathrm{Ho}=$ Horizon $*$ ex $=$ extract 

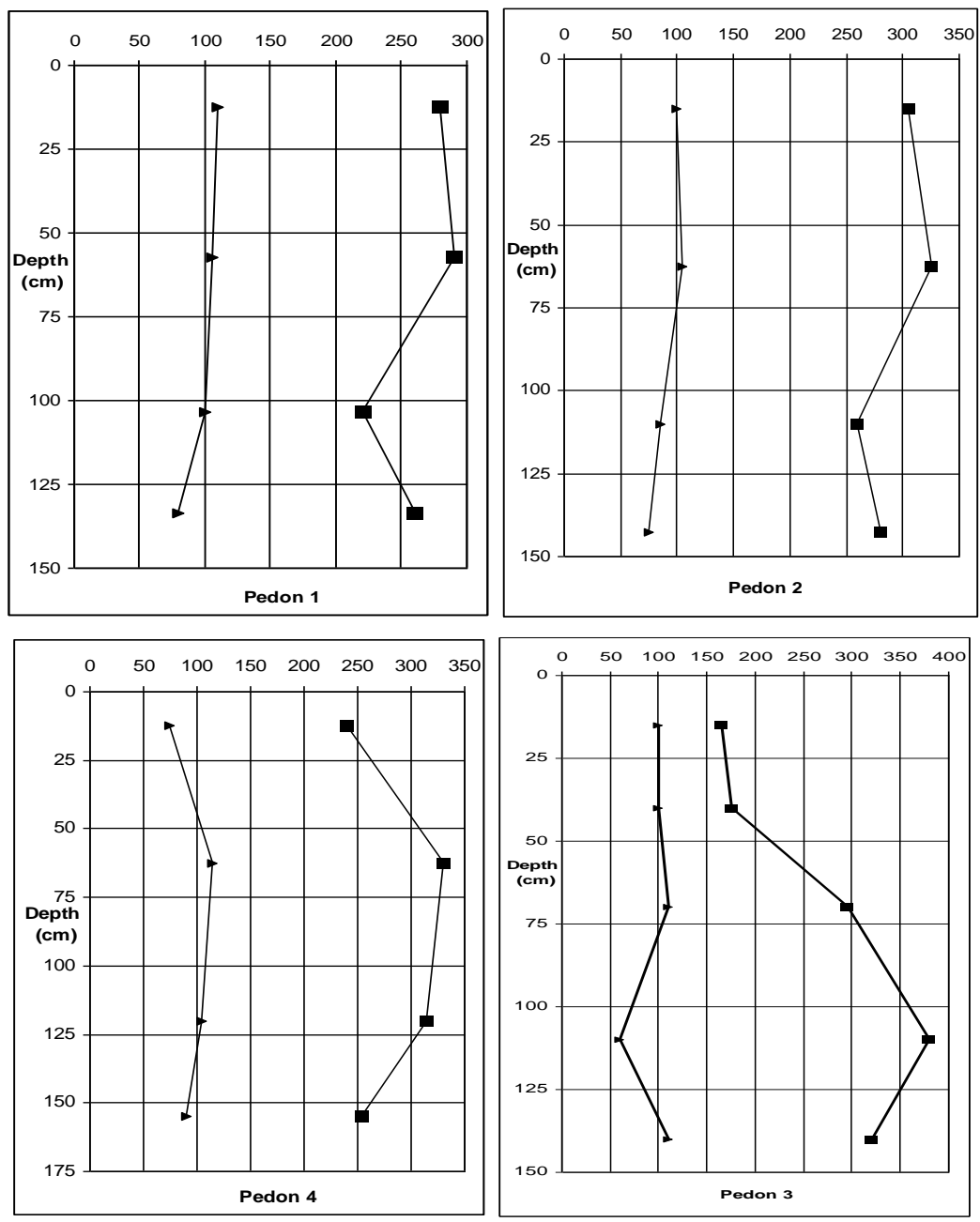

Total Lime $\left(\mathrm{g} \mathrm{kg}^{-1}\right.$ soil $)$

Active Lime $\left(\mathrm{g} \mathrm{kg}^{-1}\right.$ soil $)$

Figure 4:Distribution of total and active lime in the study pedons.

The presence of Calcic horizons reflect the effects of calcareous parent material and climatic condition and the activity of some pedogenic processes mainly decalcification and calcification.

According to the morphological ,physical and chemical properties of the studied pedons , soils were classified as Typic Argixerolls as the have Mollic surface horizons with more than $50 \%$ base saturation for more than $180 \mathrm{~cm}$ depth. They have Argillic and Calcic subsurface horizons.

\section{Conclusions}

The development of a dark, usually brownish dry colour, surface horizons of the study pedons and was due to the effects of melanisation process as related to interactions among climate and vegetation that induces the leaf fall and their decomposition and mixing with the mineral soil components. Also, the genesis of the subsurface horizons 
was initially characterized by sequences of eluviation, illuviation and lessivage processes and to some extent to in situ formation of clay minerals.

\section{References:}

- Ahmad, S. M. 2005. Natural map of Iraqi Kurdistan region.

- Al-Agidi, W.K.H. 1986. Pedology-soil survey and classification. Mosul Univ. Iraq.

- Avery, B.W. and C.L. Bascomb. 1982. Soil survey laboratory methods. Rothmaster experimental station, Harpenden, Herts. AL 52 JQ.

- Black, C. A. 1965. Methods of soil analysis. Soc. of Agronomy. No.9.Part 1 and 2.

- Blake, G. R. 1965a. Bulk density. In: Black, C. A. (Ed.). Methods of soil analysis. Part 1. Am. Soc. of Agron., Madison Wisconsin, No. 9. PP: 371-373.

- Blake, G. R. 1965b. Bulk density. In: Black, C. A. (Ed.). Methods of soil analysis. Part 2. Am. Soc. of Agron., Madison Wisconsin, No. 9. PP: 374-390.

- Buringh, P. 1960. Soil and soil condition in Iraq. Ministry of Agriculture. Baghdad, Iraq.

- Chapman, H.D. and P.E. Pratt. 1961. Methods of analysis for soil, plant and waters. Univ. of California press California. U.S.A.

- Dixit, S.P. 1978. Measurement of the mobility of soil colloids.European J. Soil Sci. 29:557 -566.

- Dunnington, H.V. 1958. Generation, migration, accumulation and dissipation of oil in northern of Iraq. In. L.G. Weeks (ed). Habitat of Oil. Amer.Assoc. Petroleum Geologist. PP: 1194-1251.

- Eswaran, H., and A.F. Al-Barzanji. 1974. Evidence for the neoformation of attapulgitein some soils of Iraq. rans. 10th Int. Congr. Soil Sci., Nauk, Moscow. 7:154-161.

- Eswaran, H. and C. Sys.1979. Argillic horizon formation in low activity clay soils, formation and significance to classification. Pedologie. 29:175-190.

- FAO (Food and Agriculture Organization) of U.N. 2000. Agricultural pest and their control principles. Offset press, Erbile-Iraq.

- Galet, D. 1972. Dosage du calcaire actif. Methods du division technique. Solaigue Nimes. France. PP: 37-38.

- Gregorich, E.G., L.W.Turchenek, M.R.Carter, and D.A.Angers. 2001. Soil and Environmental Science Dictionary. Boca Raton, FL: CRC Press. 577 pp . 
- Hesse, P. R. 1972. A text book of soil chemical analysis. Chemical publ. Co. Inc. New York-U.S.A.

- Jackson, M. L. 1956. Soil chemical analysis. Advanced course. Univ. Dept. of Wisconsin, Collage of agri. Madison.

- Jackson, M.L. 1958. Soil chemical analysis. Prentice-Hall, Englewood Cliffs, NJ.

- Jackson, M. L. 1979. Soil chemical advanced course. 2nd ed-publ. by the author, Madison, W.I. U.S.A.

- Kelley, W.P. 1948. Cation exchange in soil. Reinhold publishing crop., New York. U.S.A.

- Kharrufa, N. S. 1985. Simplified equation for evaportranspiration in arid regions. Beitrage Zure Hydrology. No. 5. PP: 39-47.

- Kilmer, V.J. and L.T. Alexander. 1949. Methods of making mechanical analysis of soils. Soil Sci. 68: 15-24.

- Mahmuod, I.J., and A.S. Muhaimeed. 2007. Characteristics, formation, and classification of alluvial soils of Naft valley in Mandali area. Iraqi J. Soil Sci. $1: 138-144.2001$

- McKeague, J. A. and R. J. St. Arnaud. 1969. Pedotranslocation: eluviationsilluviation in soils during the Quaternary. Soil Sci. 107:428-434.

- Miller, B. J. 1983. Ultisols. In: L. P. Wilding, N. E. Smeck, and G. F. Hall, editors, Pedogenesis and Soil Taxonomy II: The Soil Orders. Elsevier, Amsterdam, the Netherlands. 283-323.Developments in Soil Science. Vol. 11 Part B.

- Michel, E., S. Majdalani, and L. Di-Pietro. 2010. How differential capillary stresses promote particle mobilization in macroporous soils: A novel conceptual model. Vadose Zone J. 9:307-316.

- Muhaimeed, A.S. Soil survey and classification. Mosul Univ. Press, Iraq.1994.

- Muhaimeed, A.S., A. Alfalihi, E. Alaini and A. Taha. 2014. Developing land suitability maps for some crops in Abu-Ghraib usingremote sensing and GIS. J. Remote Sensing and GIS. 2: 16-23.

- Muhaimeed, A.S. Morphology and natural formation of some soils in northern Al-Jazera project. Iraqi J. Sci. 4:885-895. 1991.

- Muhaimeed, A.S., A.S. Al-Shikihi, S.K. Esa, and M.A. Jamal. Comparison of some properties of some properties of soils on both sides of great Zabriver in Aski-Kalk. Zanco. 4:75-88. 2000.

- Muhaimeed, A.S., and I.J. Mohammad.Characteristics, formation, and 
classification of alluvial soils of Naft valley in Manadali area. Iraqi J. Soil Sci. 1:138-144.2001.

- Muhaimeed, A.S., and K.A. Saliem. 2001. Micromorphological features of gypsiferoussoils and their effects on growth and penetration of plant roots. Iraqi J. Soil Sci. 1:154-160.

- Muhaimeed, A.S., and Salaiman.Nature of formation and classification of Vertisols in northern Iraq. Mesopotamian J. Agric. 22:121-134.1990.

- Muhaimeed, A. S.; S. N. Aziz and I. M. Amin. 2013. Genesis of Argilic and Calcic horizons in some northern Iraqi soils. ARPN Journal of Agricultural and Biological Science. Vol. 8. No. 1. PP: 29-34.

- Naqash, A. and A. Hambarsom. 1985. The geomorphology, structural geology and Iraq geology. College of Science. Baghdad Univ. Iraq.

- Nelson, D. W. and L.E. Sommer. 1982. Total carbon, organic carbon, and organic matter. PP: 539-579. In A.L. Page (ed.) Methods of Soil Analysis. 2nd Ed. ASA Monogr.. Amer. Soc. Agron. Vol. 9. No. 2. Madison. WI.

- Papanicolaou, E.P. 1976. Determination of cation exchange capacity of calcareous soils and their percent base saturation. Soil Sc. P: 121.

- Phillips, J.D. 2007. Development of texture contrast soils by a combination of bioturbation and translocation. Catena. 70:92-104.

- Piper, C. S. 1950 Soil and Plant Analysis. Interscience Publishers, Inc., New York.

- Porta, J., M.Lopez-Acevedo, and C.Roquero.1994.Edafologia. Madrid: Editions Mundi-Prensa. 807 pp.

- Richards, L. A. 1954. Diagnosis and improvement of saline and alkali soil. U.S.D.A. Handbook No. 60.

- Ryan, J.N., T.H. Illengasekare, M.I. Litaor, and R. Shannon. 1998. Particle and plutonium mobilization in macroporous soils during rainfall simulations. Environ. Sci. Technol. 32:476-482.

- Schaetzl, R.J. and S. Anderson. 2005. Soils: Genesis and geomorphology. Cambridge, University Press, Cambridge.

- Sharma, P., M. Flury, and J. Zhou. 2008. Detachment of colloids from a solid surface by a moving air-water interface. J. Colloid Interface Sci. 326:143-150.

- Soil Survey Staff. 1993. National soil survey handbook. Title 430-Vol. (Washington, D.C.: USDA Natural Resources conservation service).

- Soil Survey Staff. 1999. Soil Taxonomy. A basic system of soil classification for 
making and interpreting soil surveys. 2nded. The US government printing office, Washington, DC.

- Soil Survey Staff. 2006. Keys to soil taxonomy. Hand book. 10th ed. Natural Resources conservation service. Washington D.C.

- Soil Survey Staff. 2010. Keys to Soil Taxonomy. 11th ed. United States Department of Agriculture. Natural Resources Conservation Service. Washington D.C.

- Sprague, L.A., J.S. Herman, G.M. Hornberger, and A.L. Mills. 2000. Atrazine adsorption and colloid-facilitated transport through the unsaturated zone. J. Environ. Qual. 29:1632-1641.

- Thorp, J and Smith, G. D. 1949. Higher Categories of Soil Classifications: Order, Suborder and Great Soil Groups. Soil Science, 67: 117-126. (Classical article on the higher categories of the system of soil classification as used in the USA during the mid-twentieth century).

- Vomocil, J. A. 1965. Porosity. In: Black, C. A. (Ed.). Methods of soil analysis. Part 1. Am. Soc. of Agron., Madison Wisconsin, No. 9: PP: 315-318.

- Walkley, A. and I. A. Black. 1934. An Examination of Degtjareff Method for Determining Soil Organic Matter and a Proposed Modification of the Chromic Acid Titration Method. Soil Sci. No. 37. PP: 29-37.

- Yoseef, A.F. 1999. Devices and methods of soil and water analysis. Malic Sood Univ. Sodia Arabic.

- Zhuang, J., J.F. McCarthy, J.S. Tyner, E. Perfect, and M. Flury. 2007. In-situ colloid mobilization in Hanford sediments under unsaturated transient flow conditions: effect of irrigation pattern. Environ. Sci. Technol.41:3199-3204. 